\title{
Perkembangan Urban Sprawl Kota Semarang pada Wilayah Kabupaten Demak Tahun 2001-2012
}

\author{
Reni Mujiandari ${ }^{1}$ \\ Biro Perencanaan dan Hukum, Badan Informasi Geospasial, Kabupaten Bogor
}

Artikel Masuk : 28 Mei 2014

Artikel Diterima : 30 Juli 2014

\begin{abstract}
Urban sprawl merupakan fenomena yang terjadi akibat perkembangan kota yang semakin pesat, tetapi memiliki keterbatasan lahan sehingga perkembangan kota semakin meluas ke wilayah pinggiran (sub-urban). Wilayah sub-urban yang masih tergantung kepada kota inti juga menjadi salah satu pemicu proses urbanisasi terjadi di wilayah pinggiran tersebut (Soetomo, 2009). Fenomena tersebut terjadi di Kota Semarang yang terus berkembang, tetapi memiliki keterbatasan lahan. Kondisi tersebut menyebabkan terjadinya perkembangan kota hingga melewati batas administrasi salah satunya ke arah Kabupaten Demak. Penelitian ini bertujuan untuk mengkaji bagaimana perkembangan sprawl Kota Semarang pada wilayah Kabupaten Demak selama tahun 2001-2012. Urban sprawl pada penelitian ini ditinjau dari dua dimensi yaitu dimensi fisikal dan non fisikal. Dimensi fisikal meliputi pemanfaatan lahan, kepadatan bangunan, fungsi bangunan dan tingkat aksesibilitas. Dimensi non fisikal meliputi kepadatan penduduk dan mata pencaharian agraris penduduk. Sprawl Kota Semarang pada wilayah Kabupaten Demak selama tahun 2001-2012 telah bertambah seluas 498,685 Ha $(32,23 \%)$, yang terdiri dari perubahan dari urban sprawl menjadi non-urban sprawl sebesar 488,278 ha dan perubahan dari non-urban sprawl menjadi urban sprawl sebesar 986,963 ha. Perkembangan sprawl memiliki pola kombinasi ribbon development dan leap frog development. Wilayah Kabupaten Demak dengan jarak 7,5-10 km dari pusat Kota Semarang (ring 1) merupakan wilayah yang mengalami perkembangan urban sprawl terbesar. Hal ini menunjukan bahwa jarak terhadap pusat kota menjadi salah satu faktor yang berpengaruh terhadap terjadinya sprawl. Untuk mengatasi perkembangan sprawl agar tidak semakin meluas diperlukan kebijakan mengenai arahan pengembangan perumahan pada kawasan urban sprawl, penambahan fasilitas umum dan penyediaan sarana dan prasarana angkutan masal yang terintegrasi dengan terminal terdekat di Kota Semarang.
\end{abstract}

Kata kunci: urban sprawl, dimensi fisik, dimensi non fisik

\begin{abstract}
Limited land resulted city expansion towards the periphery by urbanization. Suburban area is still depends on the city core, which is known as urban sprawl (Soetomo, 2009). Urban sprawl in Greater Semarang passed the administrative boundaries, as example in Demak District. The purpose of study is to assess urban sprawl in Greater Semarang (a case in Demak District). In this study, urban sprawl defined in two dimensions, physical and nonphysical dimensions. Physical dimensions include land use, building density, building function and the level of accessibility. Non- physical dimensions include population density and population of agricultural livelihoods. Urban sprawl in study area during 2001-2012 has been increased 498.685 ha $(32.23 \%)$ which consists of the change from urban sprawl into nonurban sprawl 488.278 ha and changes of non-urban sprawl into urban sprawl $986.963 \mathrm{ha}$.
\end{abstract}

\footnotetext{
${ }^{1}$ Korespondensi Penulis: Biro Perencanaan dan Hukum, Badan Informasi Geospasial, Kabupaten Bogor Email: reni.mujiandari@gmail.com
} 


\section{Perkembangan Urban Sprawl Kota Semarang pada Wilayah Kabupaten Demak Tahun 2001-2012}

Development of sprawl has a combination of ribbon development and leapfrog development. Area with distance of 7.5-10 km from the center of Semarang City (ring 1) is the largest growth of urban sprawl. This shows that the distance to the city center to be one of the factors that influence sprawl. Direction of development of new residential is needed to integrated with other existing settlement. Another policy that needs to be considered is the provision of mass transportation facilities and infrastructure so that people living in urban sprawl areas do not need to use a personal vehicle to go to work or to the center of Semarang.

Keyword: urban sprawl, physical dimensions, non- physical dimensions

\section{Pendahuluan}

Pengertian urbanisasi yang lebih luas disampaikan oleh Soetomo (2009), dimana urbanisasi merupakan proses bergesernya masyarakat dari kehidupan pedesaan ke perkotaan. Perubahan wilayah pedesaan menjadi perkotaan dapat terjadi melalui sub urbanisasi, peri urbanisasi dan rurbanisasi. Secara tidak langsung urbanisasi dapat mengakibatkan pertumbuhan kota baik yang terkait jumlah penduduk maupun fisik kota. Tidak semua pertumbuhan kota sesuai dengan apa yang telah direncanakan. Terkadang pertumbuhan perkotaan terjadi di tengah-tengah daerah pedesaan yang mungkin disebabkan adanya jaringan jalan baru atau jalan raya utama.. Semakin berkembangnya penduduk dan semakin tingginya arus urbanisasi menyebabkan terjadinya urban sprawl yaitu proses perembetan kenampakan fisik kekotaan ke arah luar (Yunus, 2008).

Sampai saat ini masih terjadi perdebatan mengenai pengertian urban sprawl, pada umumnya sprawl didefinisikan sebagai tingkat kepadatan yang rendah baik itu kepadatan fisik bangunan maupun kepadatan penduduk. Urban sprawl merupakan salah satu bentuk dari urban growth yang cenderung kearah negatif. Urban sprawl dapat juga didefinisikan sebagai salah satu bentuk perkembangan kota dari segi fisik dapat dilihat dari bertambahnya gedung secara vertikal maupun horisontal, yang diikuti dengan alih fungsi lahan di sekitar kota (urban periphery). Perumahan baru, jalan, dan bangunan komersial menyebabkan daerah perkotaan tumbuh lebih jauh ke pedesaan, dan meningkatkan kepadatan pemukiman di daerah yang sebelumnya bersifat pedesaan. Pertumbuhan kota terjadi jauh keluar pinggiran kota terkadang melewati batas-batas administrasi. Ukuran kota yang mengalami sprawl terus membesar seolah-olah menyatu dengan kota-kota di sekitarnya sehingga menjadikan dua atau lebih kawasan yang secara administratif berbeda (terpisah) namun jadi satu kesatuan kenampakan kekotaan (kota metropolitan) dengan bentuk dan fungsi-fungsi bangunan yang berkarakteristik kota. Urban sprawl merupakan masalah utama dalam proses pembangunan perkotaan negara-negara Barat pada abad ke-20 disertai dengan serangkaian isu-isu lingkungan dan sosial-ekonomi, namun hal tersebut telah mendapatkan perhatian lebih (Feng, 2009).

Menurut Yeates dan Garner (1980), selain disebabkan oleh peningkatan kebutuhan ruang, sprawl juga disebabkan karena adanya perubahan kemampuan sistem transportasi, pembangunan perumahan dan keberadaan infrastruktur. Munculnya kawasan-kawasan perumahan yang tersebar, tidak teratur dan tidak terintegrasi satu sama lain di daerah pinggiran munculkan ruang-ruang kosong baik antar kawasan perumahan maupun antara kawasan perumahan dengan pusat kota. Hal tersebut menyebabkan tidak efisiennya penyediaan infrastruktur karena mahalnya biaya pengadaan tidak sebanding dengan jumlah penggunanya. Sehingga tidak salah apabila sprawl didefinisikan sebagai proses pertumbuhan daerah pinggiran secara leapfrog dari inti kota, dimana dengan pertumbuhan kota yang tidak compact menyebabkan sarana dan prasarana kota menjadi tidak efisien (Burchell et al, 2005). Menurut Almeida (2005), karena tidak adanya sebuah definisi yang universal mengenai urban sprawl, maka pemetaan lahan terbangun merupakan awal yang tepat dalam mempelajari urbanisasi. Peta memberikan gambaran pertumbuhan perkotaan yang mengarah pada urban. Perkembangan kota dapat dipetakan dengan menggunakan data time series untuk membandingkan besarnya kurun waktu tertentu.

Fenomena urban sprawl biasanya terjadi pada kota-kota besar, salah satunya pada kawasan Mega Urban Semarang. Keterbatasan lahan di dalam Kota Semarang menyebabkan terjadinya 
perkembangan kota menjalar ke wilayah lain disekitarnya, salah satunya ke arah Kabupaten Demak. Apabila dilihat Kabupaten Semarang, Kendal, Grobogan dan Demak mempunyai persamaan yaitu letaknya yang langsung berbatasan dengan Kota Semarang. Namun pada kenyataannya alih fungsi penggunaan lahan di Kabupaten Demak memiliki peringkat yang paling tinggi. Pada umumnya keberadaan urban sprawl di suatu wilayah ditandai dengan munculnya permukiman di pinggiran kota, demikian pula yang terjadi di wilayah Kabupaten Demak, permukiman baru berkembang di sebagian Kecamatan Mranggen. Selain itu dapat dilihat juga perubahan penggunaan lahan pada sepanjang koridor jalan yang menghubungan Kota Semarang dengan Kabupaten Demak yang semula lahan pertanian menjadi area terbangun. Beberapa tahun terakhir ini, Kecamatan Mranggen dan Sayung di Kabupaten Demak menunjukkan perkembangan yang sangat pesat. Di Kecamatan Mranggen muncul kecenderungan tumbuh kawasan permukiman baru. Sedangkan yang terjadi di Kecamatan Sayung adalah kecenderungan tumbuhnya kawasan industri di sepanjang koridor jalan Semarang-Demak. Bedasarkan hal tersebut maka wilayah Kabupaten Demak yang berbatasan dengan Kota Semarang dapat dikatakan sebagai daerah sprawling dari Kota Semarang. Perkembangan urban sprawl Kota Semarang yang terjadi di wilayah Kabupaten Demak terindikasi dalam perkembangan ribbon development dan leapfrog development.

Adapun tujuan penulisan adalah untuk mengkaji perkembangan sprawl Kota Semarang yang terjadi pada wilayah Kabupaten Demak dalam tahun 2001-2012. Paper ini terdiri dari lima bagian yaitu pendahuluan, variabel pengukuran urban sprawl, karakteristik sprawl Kota Semarang pada wilayah Kabupaten Demak, analisis perkembangan urban sprawl dan kesimpulan.

\section{Wilayah Studi dan Variabel Pengukuran Urban Sprawl}

Fokus penelitian adalah wilayah Kabupaten Demak pada jarak $20 \mathrm{Km}$ dari pusat Kota Semarang meliputi Kecamatan Mranggen, Sayung, Guntur, Karangawen dan Karangtengah. Letak Kecamatan Mranggen dan Sayung yang berbatasan langsung dengan Kota Semarang menyebabkan kehidupan masyarakat di kedua kecamatan tersebut telah membaur dengan kehidupan masyarakat Kota Semarang. Kondisi ini memberikan gambaran dimana masyarakat pada Kecamatan tersebut merupakan masyarakat campuran antara masyarakat desa dengan masyarakat kota. Secara historis, telah dikenal bahwa penduduk Kabupaten Demak merupakan masyarakat yang hidup dari pertanian telah bergeser pada sektor usaha perdagangan dan jasa dan industri (non pertanian). Selain itu, indikator lain adalah terjadinya perubahan penggunaan lahan dari lahan pertanian menjadi non pertanian. Hal ini bisa kita lihat adanya pemanfaatan lahan untuk pengembangan permukiman, industri serta adanya permintaan dari sektor usaha untuk mengembangkan kegiatannya. Kondisi ini ditunjang oleh posisi Kabupaten Demak yang cukup strategis dan berdekatan dengan Kota Semarang yang dilalui jalan regional Semarang-Purwodadi dan Semarang-Kudus.

Pada penelitian ini urban sprawl ditinjau dari dua dimensi yaitu dimensi fisik spasial dan dimensi non fisikal sebagaimana pendapat Smailes dalam Yunus (2006). Dimana karakteristik lahan didefinisikan sebagai klasifikasi bentuk pemanfaatan lahan (Yunus, 2006; Torrens, 2008; Feng, 2009). Karakteristik bangunan didefinisikan sebagai kepadatan bangunan (Yunus, 2006; Torrens, 2008) dan fungsi bangunan (Yunus, 2006), sedangkan karakteristik sirkulasi didefinisikan sebagai tingkat aksesibilitas (Torrens, 2008). Dimensi non fisikal didefinisikan sebagai kepadatan penduduk (Torrens, 2008) dan mata pencaharian penduduk (Yunus, 2006). 


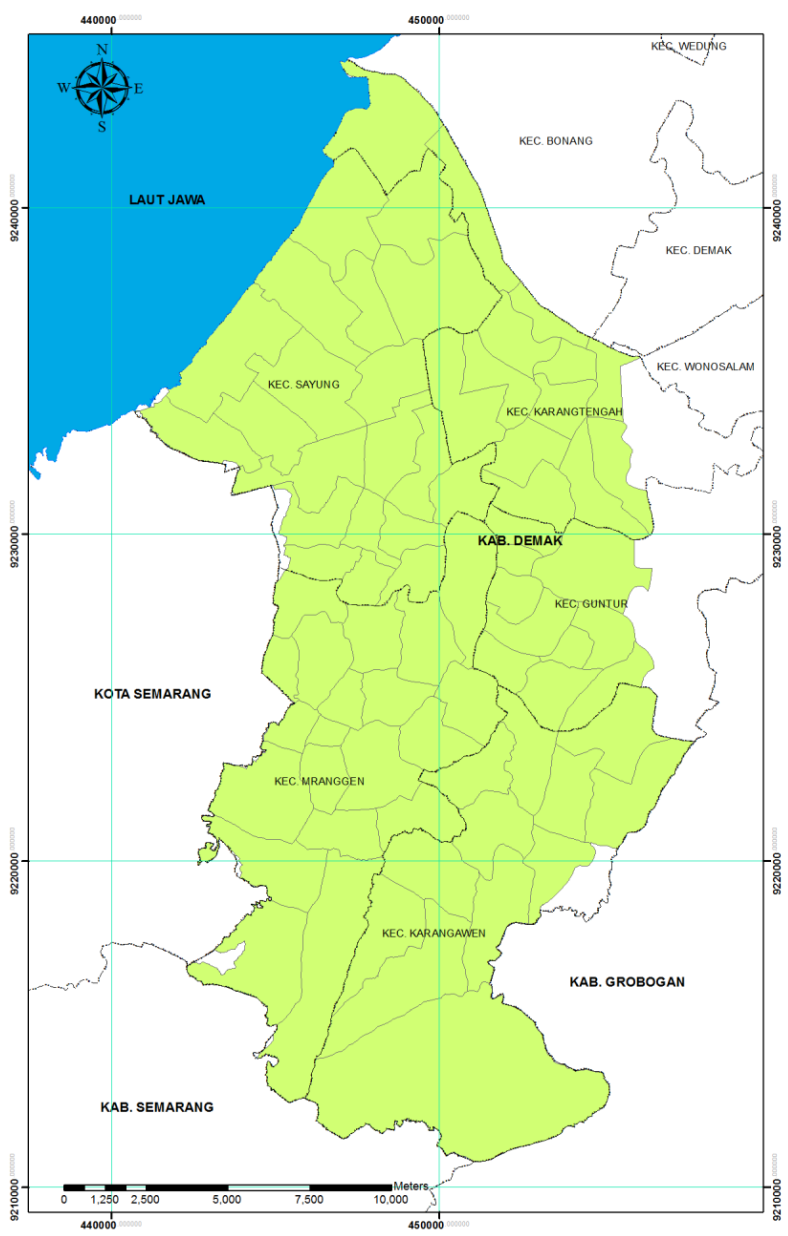

Gambar 1. Peta Wilayah Studi

Tabel 1. Parameter dan Bobot Variabel Urban Sprawl Ditinjau dari Dimensi Fisik

\begin{tabular}{|c|c|c|c|c|}
\hline Variabel & Kriteria & Kelas & Skor & Bobot \\
\hline \multirow{4}{*}{$\begin{array}{l}\text { Kepadatan } \\
\text { Bangunan }\end{array}$} & Lahan tidak terbangun & Null & 0 & \multirow[t]{4}{*}{$30 \%$} \\
\hline & $<2000$ per $\mathrm{km}^{2}$ & Rendah & 3 & \\
\hline & $2000-5000$ per $\mathrm{km}^{2}$ & Sedang & 2 & \\
\hline & $>5000$ per $\mathrm{km}^{2}$ & Tinggi & 1 & \\
\hline \multirow{4}{*}{$\begin{array}{l}\text { Fungsi } \\
\text { Bangunan }\end{array}$} & Lahan tidak terbangun & Null & 0 & \multirow[t]{4}{*}{$30 \%$} \\
\hline & $\leq 2$ fungsi & Kurang & 3 & \\
\hline & 3-4 fungsi & Cukup & 2 & \\
\hline & $\geq 5$ fungsi & Lengkap & 1 & \\
\hline \multirow{4}{*}{$\begin{array}{l}\text { Tingkat } \\
\text { Aksesibilitas }\end{array}$} & Lahan tidak terbangun & Null & 0 & \multirow[t]{4}{*}{$30 \%$} \\
\hline & $>3000$ meter & Kurang & 3 & \\
\hline & $1500-3000$ meter & Sedang & 2 & \\
\hline & $<1500$ meter & Baik & 1 & \\
\hline \multirow{3}{*}{$\begin{array}{l}\text { Pemanfaatan } \\
\text { Lahan }\end{array}$} & Jalan dan sungai & Null & 0 & \multirow[t]{3}{*}{$10 \%$} \\
\hline & Non Agraris & Terbangun & 2 & \\
\hline & Agraris & $\begin{array}{c}\text { Tidak } \\
\text { Terbangun }\end{array}$ & 1 & \\
\hline
\end{tabular}


Peta pemanfaatan lahan, peta kepadatan bangunan, peta fungsi bangunan dan peta tingkat aksesibilitas di-overlay dengan pembobotan 30\% untuk peta kepadatan bangunan dan peta fungsi bangunan, dan peta tingkat aksesibilitas serta 10\% untuk pemanfaatan lahan sehingga menghasilkan peta urban sprawl ditinjau dari dimensi fisik. Peta kepadatan penduduk dan peta mata pencaharian agraris di-overlay sehingga menghasilkan peta urban sprawl ditinjau dari dimensi non fisik. Peta urban sprawl ditinjau dari dimensi fisik kemudian dioverlay dengan peta urban sprawl ditinjau dari dimensi non fisik untuk menghasilkan peta kawasan urban sprawl. Selanjutnya dilakukan analisis perkembangan urban sprawl tahun 2001-2012. Dalam analisis tersebut dilakukan proses overlay dari peta kawasan urban sprawl tahun 2001 dan 2012. Sehingga dapat diketahui perubahan luas cakupan urban sprawl dalam rentang waktu tersebut. Teknik analisis yang digunakan adalah spatial analyst dengan menggunakan GIS dan teknik deskriptif untuk menjelaskan peta yang dihasilkan. Untuk lebih jelasnya, skoring dan pembobotan masing-masing variabel dapat dilihat pada tabel berikut.

Tabel 2. Parameter dan Bobot Variabel Urban Spraw/Ditinjau dari Dimensi Fisik

\begin{tabular}{l|l|c|c|c}
\hline \multicolumn{1}{c|}{ Variabel } & \multicolumn{1}{|c|}{ Kriteria } & Kelas & Skor & \multirow{2}{*}{ Bobot } \\
\hline \multirow{2}{*}{$\begin{array}{l}\text { Kepadatan } \\
\text { Penduduk }\end{array}$} & $<1500$ per $\mathrm{km}^{2}$ & Rendah & 1 & $\mathbf{5 0 \%}$ \\
\cline { 2 - 4 } & $1500-3000 \mathrm{per} \mathrm{km}^{2}$ & Sedang & 2 & \\
\cline { 2 - 5 } & $>3000$ per $\mathrm{km}^{2}$ & Tinggi & 3 & \\
\hline \multirow{2}{*}{$\begin{array}{l}\text { Mata } \\
\text { Pencaharian }\end{array}$} & $<30 \%$ & Rendah & 3 & $\mathbf{5 0 \%}$ \\
\cline { 2 - 5 } Agraris & $30 \%-75 \%$ & Sedang & 2 & \\
\cline { 2 - 5 } & $>75 \%$ & Tinggi & 1 & \\
\hline
\end{tabular}

Tabel 3. Range Nilai penentuan Kawasan Urban SprawI

\begin{tabular}{c|c}
\hline RANGE NILAI & Kriteria \\
\hline $1-2$ & Non Urban Sprawl \\
\hline$>2$ & Urban Sprawl \\
\hline
\end{tabular}




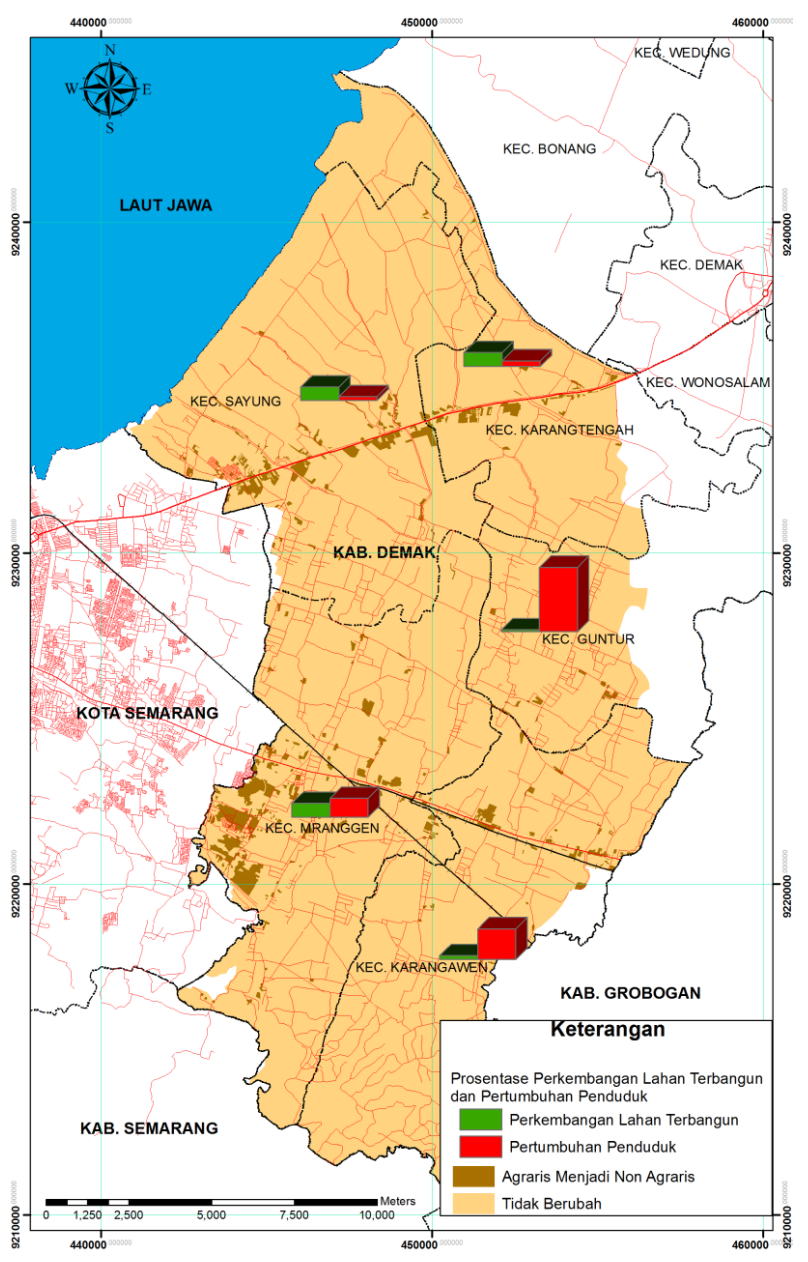

\section{Gambar 2. Peta Perubahan Lahan Agraris Menjadi Nonagraris dan Persentase Perkembangan Lahan Terbangun dan Pertumbuhan Penduduk Tahun 2001-2012}

\section{Karakteristik Sprawl Kota Semarang pada Wilayah Kabupaten Demak}

Kabupaten Demak yang menjadi fokus penelitian adalah wilayah dengan jarak $20 \mathrm{~km}$ dari pusat Kota Semarang, meliputi Kecamatan Mranggen, Sayung, Guntur, Karangawen dan Karangtengah. Kondisi wilayah perbatasan Kabupaten Demak saat ini telah memperlihatkan perkembangan yang pesat, yang dulunya masih bersifat pedesaan sekarang telah menjadi perkotaan. Secara umum dalam rentang tahun 2001-2012 penduduk Kabupaten Demak meningkat sebanding dengan peningkatan lahan terbangun. Namun pada Kecamatan Sayung dan Karangtengah terjadi peningkatan lahan terbangun yang lebih besar dibandingkan dengan peningkatan jumlah penduduk.

Peningkatan jumlah penduduk di Kabupaten Demak selain dipengaruhi oleh kelahiran juga dipengaruhi oleh migrasi. Pertambahan penduduk yang disebabkan adanya migrasi di Kabupaten Demak, mayoritas terjadi pada Kecamatan Sayung dan Kecamatan Mranggen. Migrasi yang terjadi pada Kecamatan Sayung dipengaruhi oleh adanya pertumbuhan industri yang semakin banyak di kecamatan tersebut. Sedangkan yang menjadi daya tarik Kecamatan Mranggen adalah pengembangan perumahan yang semakin menjamur pada wilayah tersebut. Urban sprawl juga dapat dilihat dari adanya perubahan kehidupan masyarakat dari sifat kedesaan menjadi bersifat kekotaan. Perubahan tersebut meliputi perilaku ekonomi, sosial, budaya, politik dan teknologi. Dari aspek ekonomi misalnya dapat dilihat dari perubahan mata pencaharian dari agraris menjadi non agraris. Dalam kurun waktu 2001-2012 jumlah penduduk agraris di wilayah studi mengalami 
penurunan sebesar $16,76 \%$. Kecamatan yang mengalami penurunan tertinggi adalah Kecamatan Mranggen yaitu sebesar 25,56\%.

\section{Analisis Perkembangan Urban Sprawl}

Berdasarkan dimensi fisikal dan non fisik, kawasan urban sprawl tahun 2001 pada wilayah studi merupakan bentuk leap frog development dengan luas 1547.437 ha. Sprawl yang terjadi pada Kecamatan Sayung dan Karangtengah sebagai akibat adanya pengembangan kawasan industri pada koridor jalan arteri Semarang-Demak yang melewati kedua kecamatan tersebut. Kondisi jalan yang baik dengan skala jalan nasional memberi kemudahan pada sektor industri dalam pengangkutan bahan mentah dan hasil industrinya. Sprawl pada kawasan selatan Kabupaten Demak terjadi pada Kecamatan Mranggen dan Karangawen, terutama pada Desa Kembangarum, Batursari dan Kebonbatur di Kecamatan Mranggen. Sprawl yang terjadi pada kawasan tersebut disebabkan karena adanya intervensi pengembang perumahan. Mereka memilih daerah ini karena harga lahannya relatif lebih murah sehingga memungkinkan untuk dikembangkan sebagai perumahan skala menengah ke bawah. Penduduk yang memilih untuk bermukim di kawasan tersebut mendapatkan kemudahan akses ke Kota Semarang karena pada daerah tersebut terdapa jalan kolektor SemarangPurwodadi.

Kawasan urban sprawl pada tahun 2012 meningkat 32,23\% dibandingkan tahun 2001 menjadi 2046.205 ha. Peningkatan luas kawasan urban sprawl terjadi pada Kecamatan Mranggen, Sayung, Karangtengah dan Karangawen. Sedangkan Kecamatan Guntur justru mengalami penurunan luas kawasan sprawl sebesar 205,92ha. Bentuk dari sprawl yang terjadi merupakan kombinasi dari ribbon development dan leap frog development. Pengembangan perumahan pada Kecamatan Mranggen merupakan akibat dari adanya pengembangan industri pada koridor Jalan Raya SemarangPurwodadi. Pengembangan industri tentunya akan menyerap tenaga kerja dengan jumlah yang besar, hal inilah yang menjadi pertimbangan para pengembang perumahan membangun perumahan baru untuk kalangan menengah kebawah. Perumahan yang dikembangkan pada Kecamatan Mranggen pada umumnya adalah perumahan dengan unit kecil. Lokasi yang dipilih pengembang pun berada jauh ke selatan dari jalan kolektor. Pertimbangan tersebut diambil untuk menekan harga jual sehingga dapat menarik penduduk untuk tinggal disana. Hal inilah yang menyebabkan pembangunan pada Kecamatan Mranggen membentuk pola leap frog development. Kondisi perumahan yang jauh dari jalan utama dan tidak dilalui oleh angkutan umum menyebabkan adanya ketergantungan penduduk pada kendaraan pribadi, sehingga berdampak pada peningkatan kepadatan jalan.

Pada Tahun 2012, industri pada koridor jalan Semarang-Demak terus mengalami peningkatan. Penyerapan tenaga kerja pada sektor ini menyebabkan penduduk sekitar beralih mata pencaharian dari sektor agraris ke industri. Berbeda dengan apa yang terjadi pada Kecamatan Mranggen dimana pengembang perumahan beramai-ramai mengembangan perumahan dengan skala kecil, pada Kecamatan Sayung dapat dikatakan tidak ada pengembangan perumahan. Hal ini dikarenakan lahan di utara jalan arteri Semarang Demak saat ini rawan terhadap rob, apabila akan dibangun perumahan dibutuhkan biaya lebih untuk meninggikan lahan dampaknya adalah harga rumah menjadi tidak terjangkau. 

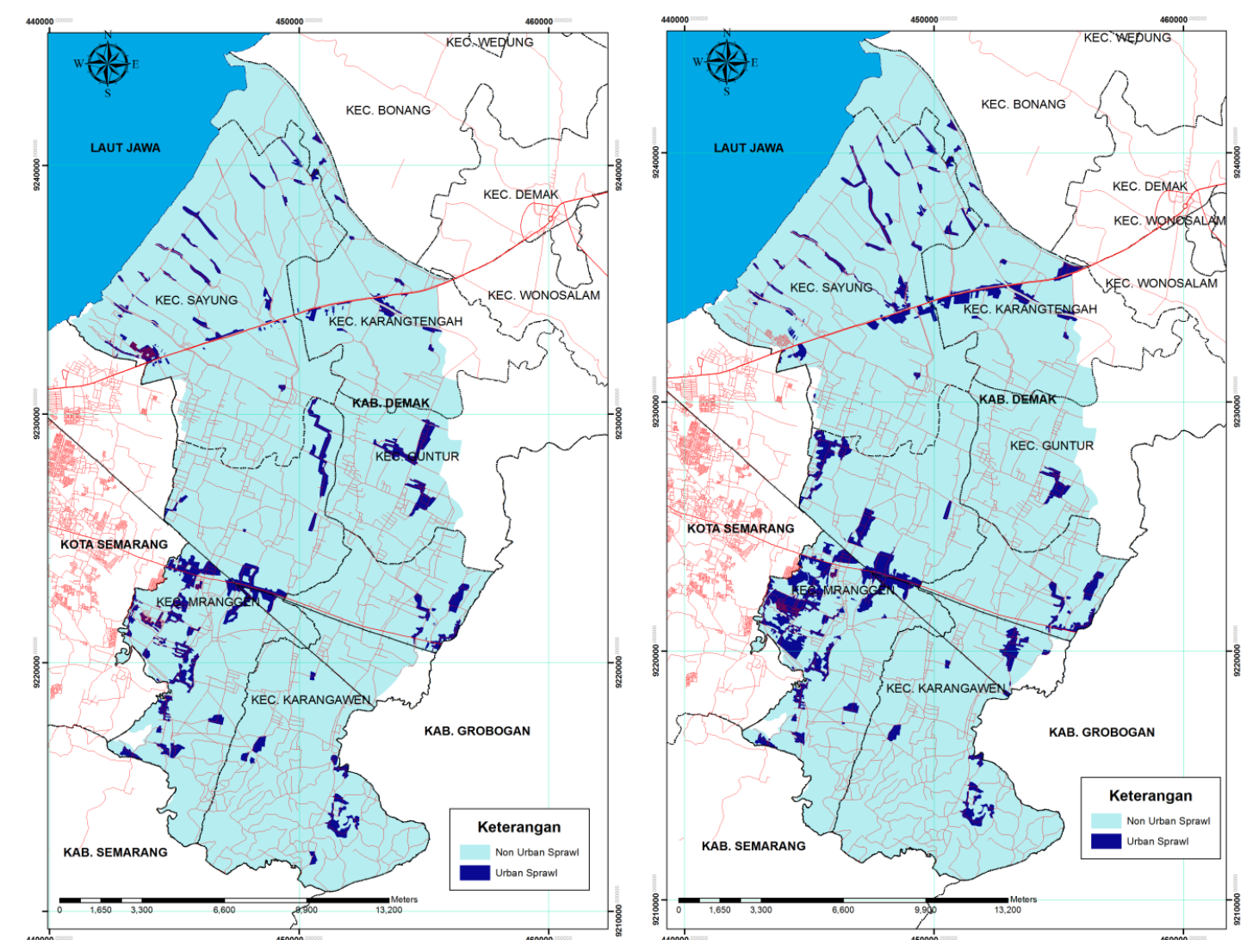

Gambar 3. Kawasan Urban Sprawl Tahun 2001 (kiri) dan Tahun 2012 (kanan)

Tahun 2001 desa dengan luas sprawl lebih dari 30\% dari luas wilayahnya terdapat pada Kecamatan Mranggen meliputi Desa Kembangarum (35\%), Desa Bandungrejo (42,5\%) dan Desa Brumbung. Sedangkan pada tahun 2012 desa dengan luas sprawl lebih dari 30\% dari luas wilayahnya terdapat pada Kecamatan Mranggen meliputi Desa Batursari (44\%), Brumbung (42,6\%), Kembangarum (42,2\%), Ngemplak (39,5\%), Wringinjajar (38,7\%). Sprawl semakin meluas dikarenakan adanya pengembangan kawasan perumahan pada beberapa desa tersebut.

Dalam kurun waktu 2001-2012 urban sprawl bertambah 498,685 ha. Apabila dilihat lebih rinci dapat diketahui bahwa dalam kurun waktu tersebut terjadi perubahan status sprawl, beberapa wilayah mengalami perubahan dari non urban sprawl menjadi urban sprawl maupun sebaliknya. wilayah yang pada tahun 2001 merupakan kawasan urban sprawl namun pada tahun 2012 tidak termasuk pada kawasan urban sprawl sebesar 488,278ha. Hal ini dikarenakan wilayah tersebut telah mengalami pemadatan permukiman yang diikuti dengan penyediaan fasilitas umum untuk melayani penduduk yang tinggal di sana. Begitu juga sebaliknya terdapat wilayah yang pada tahun 2001 tidak termasuk kedalam kawasan urban sprawl pada tahun 2012 justru terindikasi sprawl yaitu seluas 986.963ha. Hal ini dikarenakan adanya perkembangan lahan terbangun terutama permukiman yang tersebar sehingga menyebabkan tingkat kepadatan bangunan menjadi rendah serta tidak diikuti dengan penyediaan fasilitas umum untuk memenuhi kebutuhan penduduk yang tinggal pada daerah tersebut. 

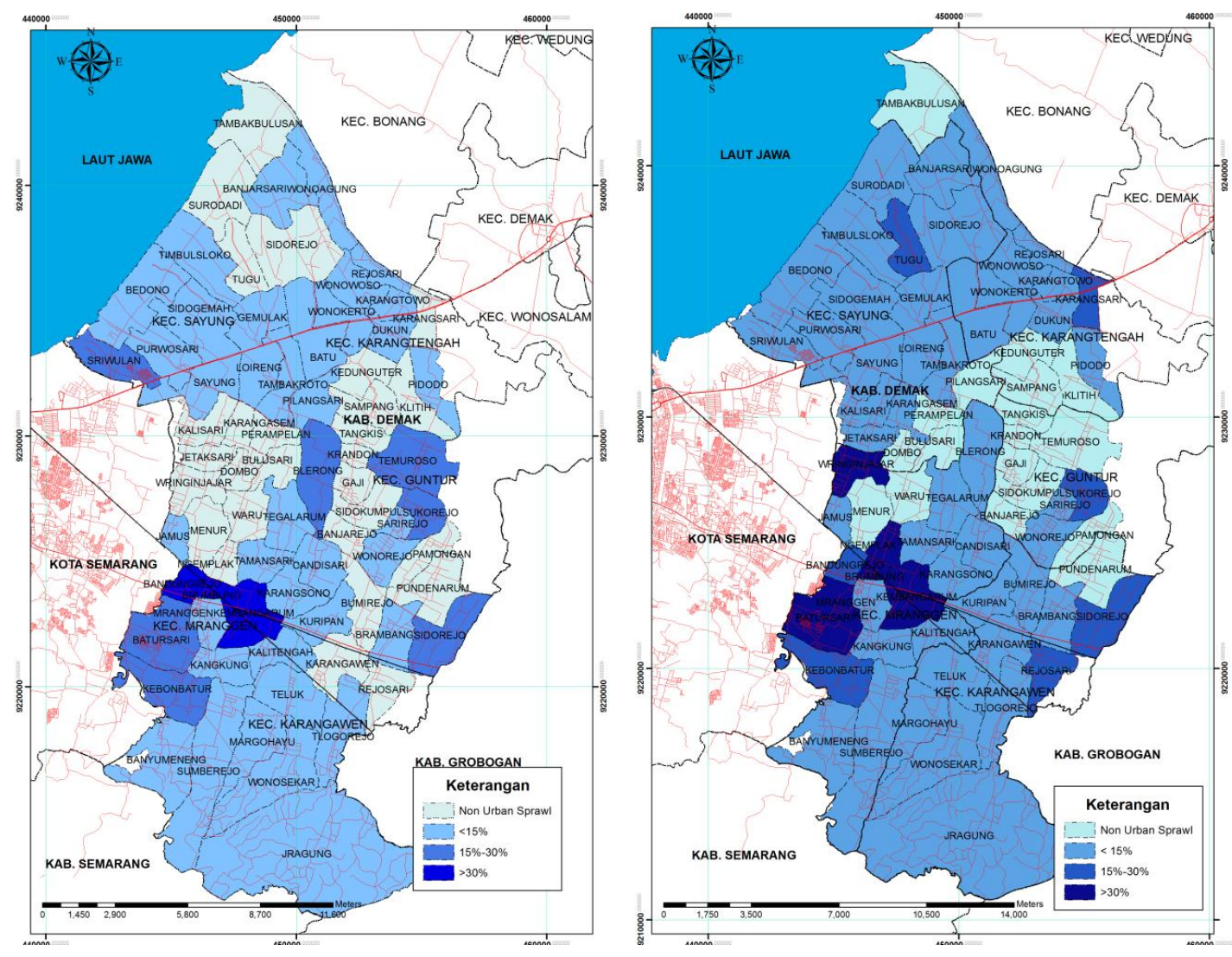

Gambar 4. Desa yang tergolong Urban Sprawl Tahun 2001 (Kiri) dan Tahun 2012 (Kanan)

Peningkatan sprawl terjadi pada Kecamatan Mranggen meliputi Desa Kangkung, Desa Ngemplak dan Desa Wringinjajar; Desa Rejosari Kecamatan Karangawen, Kecamatan Sayung meliputi Desa Kalisari, Desa Tugu, Desa Sidorejo, dan Desa Surodadi; serta Kecamatan Karangtengah meliputi Desa Karangsari dan Wonokerto. Selain terjadi peningkatan sprawl, pada wilayah studi juga terjadi penurunan tingkat sprawl. Penurunan tingkat sprawl terjadi pada Kecamatan Mranggen meliputi Desa Bandungrejo dan Desa Tamansari; Kecamatan Guntur meliputi Desa Blerong dan Temuroso; serta Kecamatan Sayung meliputi Desa Sriwulan dan Timbulsloko.

Wilayah Kabupaten Demak yang termasuk ke dalam radius 20 kilometer dari pusat kota Semarang meliputi Kecamatan Mranggen, Sayung, Karangawen, Karangtengah dan Guntur. Berdasarkan hasil analisis yang dilakukan seluruh kecamatan tersebut mengalami sprawl pada beberapa wilayah. Namun pada Kecamatan Guntur sprawl tidak semakin meluas bahkan berkurang luasnya $(205,916 \mathrm{ha})$. Peningkatan luas kawasan sprawl yang paling besar adalah pada Kecamatan Mranggen yaitu 390,598ha.

Apabila dilihat dari dimensi non fisik, perkembangan urban sprawl pada Kecamatan Karangawen dan Mranggen terjadi pada desa dengan kepadatan penduduk sedang, untuk Kecamatan Karangtengah dan Sayung pada desa dengan kepadatan penduduk rendah. Berdasarkan mata pencaharian agraris, sprawl pada Kecamatan Karangawen, Karangtengah dan Sayung terjadi pada desa dengan prosentase sedang, dan untuk Kecamatan Mranggen pada desa dengan prosentase rendah.

Sedangkan jika dilihat berdasarkan dimensi fisik perkembangan sprawl pada Kecamatan Mranggen dan Karangtengah terjadi pada lahan yang tidak terbangun. Hal ini membuktikan adanya peralihan lahan tidak terbangun menjadi lahan terbangun yang memicu terjadinya sprawl. Di Kecamatan Mranggen terjadi alih fungsi lahan tidak terbangun menjadi perumahan sedangkan di Kecamatan Karangtengah alih fungsi lahan tidak terbangun menjadi kawasan industri. Perkembangan sprawl di Kecamatan Karangawen terjadi pada lahan terbangun dengan kepadatan bangunan sedang, fungsi bangunan kurang dan aksesibilitas rendah. Sedangkan pada Kecamatan 


\section{Perkembangan Urban Sprawl Kota Semarang pada Wilayah Kabupaten Demak Tahun 2001-2012}

Sayung terjadi pada lahan terbangun dengan kepadatan bangunan rendah, dan pada lahan tidak terbangun.

Berdasarkan jarak dari pusat kota Semarang, wilayah Kabupaten Demak yang berkembang menjadi kawasan urban sprawl dalam kurun waktu 2001-2012 terbesar berada pada ring 1 yaitu jarak 7,5-10 Km. Selain mengalami perubahan menjadi kawasan urban sprawl yang terbesar $(14,13 \%)$, ring pertama ini juga merupakan kawasan yang mengalami perubahan dari urban sprawl menjadi kawasan yang lebih padat terbesar yaitu sebesar 4,87\%. Perkembangan sprawl pada ring 1 mengalami peningkatan yang cukup signifikan dikarenakan ring tersebut memiliki jarak paling dekat dengan pusat kota Semarang. Penduduk cenderung memilih lokasi tempat tinggal dengan jarak yang paling dekat dengan pusat kota namun dengan harga yang relatif masih rendah. Hal tersebut merupakan peluang yang diambil oleh para pengembang perumahan untuk mengembangan perumahan dengan tipe kecil pada daerah pinggiran. Permintaan pasar untuk perumahan tipe kecil tersebut saat ini masih sangat tinggi. Hal ini dibuktikan dengan makin menjamurnya perumahan di kawasan pinggiran Kabupaten Demak yang berbatasan dengan Kota Semarang terutama pada ring 1 (7,5-10 Km).

Perkembangan sprawl pada wilayah studi bagian utara mengikuti koridor jalan arteri dengan penggunaan lahan sebagai kawasan industri. Pemilihan lokasi untuk industri mempertimbangkan antara lain kemudahan aksesibilitas untuk mencapai pelabuhan barang, lahan yang luas dengan relief datar dan bebas banjir. Wilayah studi bangian utara meliputi Kecamatan Sayung dan Karangtengah merupakan daerah yang dilalui oleh jalan arteri Semarang-Demak dan memiliki relief yang datar serta bebas banjir. Pelabuhan Tanjung Mas Semarang dapat dengan mudah diakses dari kedua kecamatan tersebut, didukung harga lahan yang relatif lebih rendah dibandingkan dengan lahan didalam Kota Semarang serta adanya peraturan daerah Kabupaten Demak mengenai Rencana Tata Ruang Wilayah Kabupaten Demak Tahun 2011-2031 yenag menyebutkan bahwa Kecamatan Sayung dan Karangtengah merupakan kawasan yang akan dikembangkan sebagai kawasan industri, menyebabkan investor industri memilih lokasi pada kedua kecamatan tersebut. Selain faktor internal sebagai pendukung perkembangan industri pada kawasan tersebut, terdapat faktor eksternal yang mempengaruhi perkembangan industri yaitu pada wilayah Kota Semarang yang berbatasan dengan Kabupaten Demak bagian utara merupakan kawasan yang sudah dikembangkan sebagai kawasan industri. Secara tidak langsung akan mempengaruhi perkembangan industri pada daerah sekitarnya. 

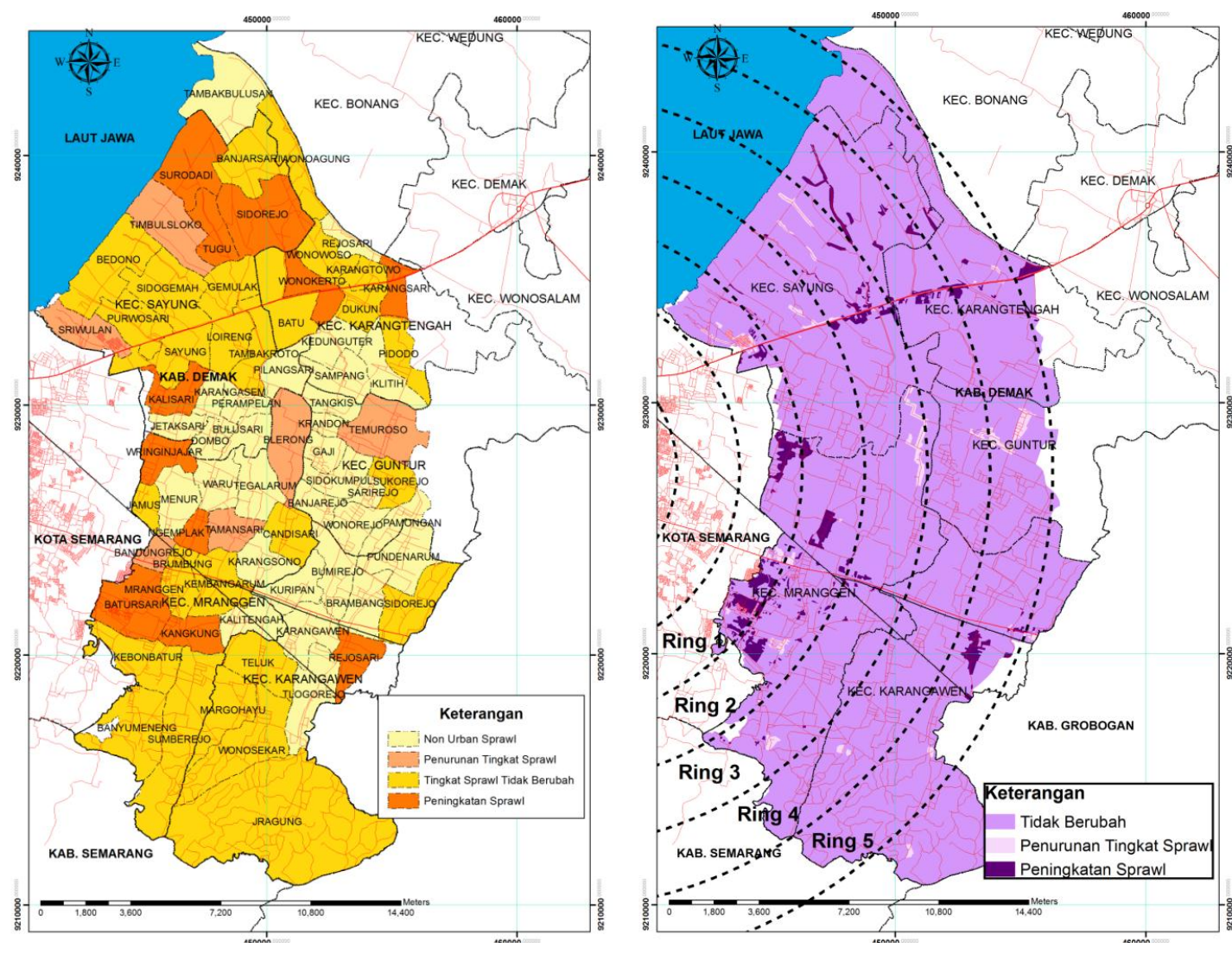

Gambar 5. Peta Perubahan Tingkat Sprawl Per Desa Tahun 2001-2012 (kiri); Peta Perubahan Urban Sprawl Per Ring Jarak dari Kota Semarang Tahun 2001-2012 (kanan)

Tabel 4. Luas Lahan yang Berkembang Menjadi Kawasan Urban Sprawl Berdasarkan Dimensi Nonfisik

\begin{tabular}{|c|c|c|c|c|c|c|c|c|c|c|c|}
\hline \multirow{2}{*}{ Variabel } & \multirow{3}{*}{$\begin{array}{l}\text { Kriteria } \\
\text { Rendah }\end{array}$} & \multicolumn{10}{|c|}{ Kecamatan } \\
\hline & & \multicolumn{2}{|c|}{ Karangawen } & \multicolumn{2}{|c|}{ Karangtengah } & \multicolumn{2}{|c|}{ Mranggen } & \multicolumn{2}{|c|}{ Sayung } & \multicolumn{2}{|c|}{ Jumlah } \\
\hline \multirow{4}{*}{$\begin{array}{l}\text { Kepadatan } \\
\text { Penduduk } \\
\text { (ha) }\end{array}$} & & 15.23 & $14.31 \%$ & 79.86 & $65.51 \%$ & 6.92 & $1.44 \%$ & 274.32 & $99.25 \%$ & 376.33 & $38.13 \%$ \\
\hline & Sedang & 91.25 & $85.69 \%$ & 42.04 & $34.49 \%$ & 302.52 & $62.75 \%$ & 2.02 & $0.73 \%$ & 437.83 & $44.37 \%$ \\
\hline & Tinggi & 0 & $0 \%$ & 0 & $0 \%$ & 172.63 & $35.81 \%$ & 0.05 & $0.02 \%$ & 172.68 & $17.50 \%$ \\
\hline & Jumlah & 106.49 & $100 \%$ & 121.89 & $100 \%$ & 482.07 & $100 \%$ & 276.40 & $100 \%$ & 986.85 & $100 \%$ \\
\hline \multirow{4}{*}{$\begin{array}{c}\text { Mata } \\
\text { Pencahari- } \\
\text { an Agraris } \\
\text { (ha) }\end{array}$} & Tinggi & 0 & $0 \%$ & 36.43 & $29.89 \%$ & 0 & $0 \%$ & 129.49 & $46.85 \%$ & 166.21 & $16.79 \%$ \\
\hline & Sedang & 106.49 & $100 \%$ & 85.46 & $70.11 \%$ & 196.04 & $40.67 \%$ & 146.86 & $53.13 \%$ & 536.97 & $54.25 \%$ \\
\hline & Rendah & 0 & $0 \%$ & 0 & $0 \%$ & 286.03 & $59.33 \%$ & 0.05 & $0.02 \%$ & 286.67 & $28.96 \%$ \\
\hline & Jumlah & 106.49 & $100 \%$ & 121.89 & $100 \%$ & 482.07 & $100 \%$ & 276.40 & $100 \%$ & 989.85 & $100 \%$ \\
\hline
\end{tabular}


Tabel 5. Luas Lahan yang Berkembang Menjadi Kawasan Urban Sprawl Berdasarkan Dimensi Fisik

\begin{tabular}{|c|c|c|c|c|c|c|c|c|c|c|c|}
\hline \multirow{2}{*}{ Variabel } & \multirow{3}{*}{$\begin{array}{l}\text { Kriteria } \\
\text { Tidak } \\
\text { Terbangun }\end{array}$} & \multicolumn{10}{|c|}{ Kecamatan } \\
\hline & & \multicolumn{2}{|c|}{ Karangawen } & \multicolumn{2}{|c|}{ Karangtengah } & \multicolumn{2}{|c|}{ Mranggen } & \multicolumn{2}{|c|}{ Sayung } & \multicolumn{2}{|c|}{ Jumlah } \\
\hline \multirow{3}{*}{$\begin{array}{l}\text { Pemanfaatan } \\
\text { Lahan (ha) }\end{array}$} & & 21.94 & $20.60 \%$ & 68.11 & $55.87 \%$ & 300.85 & $62.41 \%$ & 136.34 & $49.33 \%$ & $\mathbf{5 2 7 . 2 4}$ & $53.43 \%$ \\
\hline & Terbangun & 84.55 & $79.40 \%$ & 53.78 & $44.13 \%$ & 181.22 & $37.59 \%$ & 140.05 & $50.67 \%$ & 459.61 & $46.57 \%$ \\
\hline & Jumlah & 106.49 & $100 \%$ & 121.89 & $100 \%$ & 482.07 & $100 \%$ & 276.40 & $100 \%$ & 986.85 & $100 \%$ \\
\hline \multirow{5}{*}{$\begin{array}{c}\text { Kepadatan } \\
\text { Bangunan } \\
\text { (ha) }\end{array}$} & Null & 21.94 & $20.60 \%$ & 68.11 & $55.87 \%$ & 300.85 & $62.41 \%$ & 136.34 & $49.33 \%$ & 527.24 & $53.43 \%$ \\
\hline & Tinggi & 0 & $0 \%$ & 0 & $0 \%$ & 0.63 & $0.13 \%$ & 0 & $0.0 \%$ & 0.63 & $0.06 \%$ \\
\hline & Sedang & 84.02 & $78.90 \%$ & 35.79 & $29.36 \%$ & 180.43 & $37.43 \%$ & 0.47 & $0.17 \%$ & 300.71 & $30.47 \%$ \\
\hline & Rendah & 0.53 & $0.50 \%$ & 17.99 & $14.76 \%$ & 0.16 & $0.03 \%$ & 139.58 & $50.50 \%$ & 158.27 & $16.04 \%$ \\
\hline & Jumlah & 106.49 & $100 \%$ & 121.89 & $100 \%$ & 482.07 & $100 \%$ & 276.40 & $100 \%$ & 986.85 & $100 \%$ \\
\hline \multirow{5}{*}{$\begin{array}{l}\text { Fungsi } \\
\text { Bangunan } \\
\text { (ha) }\end{array}$} & Null & 21.94 & $20.60 \%$ & 68.11 & $55.87 \%$ & 300.85 & $62.41 \%$ & 136.34 & $49.33 \%$ & 527.24 & $53.43 \%$ \\
\hline & Lengkap & 0 & $0 \%$ & 0 & $0 \%$ & 0.57 & $0.12 \%$ & 0 & $0 \%$ & 0.57 & $0.06 \%$ \\
\hline & Cukup & 0.04 & $0 \%$ & 30.11 & $24.70 \%$ & 174.36 & $36.17 \%$ & 71.66 & $25.93 \%$ & 276.17 & $27.98 \%$ \\
\hline & Kurang & 84.51 & $79.36 \%$ & 23.67 & $19.42 \%$ & 6.29 & $1.31 \%$ & 68.39 & $24.74 \%$ & 182.87 & $18.53 \%$ \\
\hline & Jumlah & 106.49 & $100 \%$ & 121.89 & $100 \%$ & 482.07 & $100 \%$ & 276.40 & $100 \%$ & 986.85 & $100 \%$ \\
\hline \multirow{5}{*}{$\begin{array}{l}\text { Aksesibilitas } \\
\text { (ha) }\end{array}$} & Null & 21.94 & $20.60 \%$ & 68.11 & $55.87 \%$ & 300.85 & $62.41 \%$ & 136.34 & $49.33 \%$ & 527.24 & $53.43 \%$ \\
\hline & Baik & 0.06 & $0.05 \%$ & 30.32 & $24.88 \%$ & 174.41 & $36.18 \%$ & 3.02 & $1.09 \%$ & 207.81 & $21.06 \%$ \\
\hline & Sedang & 84.49 & $79.35 \%$ & 23.46 & $19.25 \%$ & 6.70 & $1.39 \%$ & 22.88 & $8.28 \%$ & 137.54 & $13.94 \%$ \\
\hline & Kurang & 0 & $0 \%$ & 0 & $0 \%$ & 0.11 & $0.02 \%$ & 114.15 & $41.30 \%$ & 114.26 & $11.58 \%$ \\
\hline & Jumlah & 106.49 & $100 \%$ & 121.89 & $100 \%$ & 482.07 & $100 \%$ & 276.40 & $100 \%$ & 986.85 & $100 \%$ \\
\hline
\end{tabular}

Perkembangan sprawl pada wilayah studi bagian selatan yaitu pada Kecamatan Mranggen dan Karangawen disebabkan karena adanya pengembangan kawasan perumahan. Pemilihan lahan untuk lokasi perumahan dipengaruhi oleh harga lahan yang relatif lebih rendah, daerah yang datar dan bebas bencana seperti banjir dan tanah longsor. Hal ini dilakukan untuk menekan harga jual perumahan sehingga dapat dijangkau oleh masyarakat. Harga lahan di Kota Semarang yang semakin meningkat menyebabkan penduduk lebih memilih lokasi hunian pada daerah pinggiran Kota Semarang bahkan hingga wilayah Kabupaten Demak yang berbatasan dengan Kota Semarang seperti pada Kecamatan Mranggen.

\section{Kesimpulan}

Kawasan urban sprawl selama tahun 2001-20012 telah mengalami peningkatan sebesar $32,23 \%$, dengan pola kombinasi ribbon development dan leap frog development. Perkembangan dengan pola ribbon development terjadi pada sepanjang koridor Jalan Arteri Semarang-Demak dengan dominasi penggunaan lahan sebagai kawasan industri, sedangkan pola leap frog development terjadi pada Kecamatan Mranggen dan Kecamatan Sayung dengan dominasi penggunaan lahan sebagai permukiman dan perumahan. Wilayah Kabupaten Demak dengan jarak 7,5-10 km dari pusat Kota Semarang (Ring 1) merupakan wilayah yang mengalami perkembangan urban sprawl terbesar, hal ini menunjukan bahwa jarak terhadap pusat kota menjadi salah satu faktor yang berpengaruh terhadap terjadinya sprawl. Urban sprawl yang terjadi pada wilayah Kabupaten Demak merupakan permasalahan yang harus segera diselesaikan. Yang menjadi permasalahan adalah bagaimana upaya untuk mengelola urban sprawl tersebut sehingga perkembangannya dapat ditekan seminimal mungkin. Berdasarkan hasil penelitian maka dapat 
diberikan rekomendasi kebijakan untuk mengantisipasi perluasan sprawl antara lain dengan memberikan arahan pengembangan perumahan pada kawasan urban sprawl sehingga akan terjadi pemadatan pada kawasan tersebut. hal ini bertujuan agar perumahan baru dapat terintegrasi dengan permukiman lain yang telah ada lebih dahulu sehingga tidak terjadi pemborosan biaya dalam penyediaan sarana dan prasarana yang diperlukan. Selain itu perlu dilakukan pengembangkan struktur jaringan jalan yang menghubungkan kawasan urban sprawl ke akses jalan utama, serta penyediaan sarana dan prasarana angkutan masal yang terintegrasi dengan terminal terdekat di Kota Semarang. Sehingga penduduk yang tinggal di kawasan urban sprawl tidak perlu menggunakan kendaraan pribadi untuk menuju ke tempat kerja maupun ke pusat Kota Semarang. Hal ini dapat menekan penggunaan bahan bakar, menurunkan jumlah emisi polutan dari kendaraan bermotor.

\section{Daftar Pustaka}

Almeida, B. 2005. A GIS Assessment of Urban Sprawl in Richmond, Virginia. Blacksburg: Virginia Polytechnic Institute and State University.

Burchell, Robert W; Downs, Anthony; McCann, Barbara; Mukherji, Sahan. 2005. Sprawl Costs, Economic Impacs of Unchecked Development. Washington DC: Island Press.

Feng, L. 2009. Applyng Remote Sensing and GIS on Monitoring and Measuring Urban Sprawl - A Case Study of China. II International Conference on Sustainibility Measurement and Modelling (pp. 1-10). Barcelona: CIMNE.

Soetomo, S. 2009. Urbanisasi \& Morfologi, Proses Perkembangan Peradaban \& Wadah Ruang Fisiknya: Menuju Ruang Kehidupan Yang Manusiawi. Yogyakarta: Graha Ilmu.

Torrens, P. M. 2008. A Toolkit for Measuring Sprawl. Appl. Spatial Analysis , 1, 5-36.

Yeates, Maurice; Garner, Barry. 1980. The North American City. New York: Harper \& Row Publishers.

Yunus, H. S. 2006. Megapolitan: Konsep, Problematika dan Prospek. Yogyakarta: Pustaka Pelajar. 2008. Dinamika Wilayah Peri Urban, Determinan Masa Depan Kota. Yogyakarta: Pustaka Pelajar. 
142 Perkembangan Urban Sprawl Kota Semarang pada Wilayah Kabupaten Demak Tahun 2001-2012

JURNAL WILAYAH DAN LINGKUNGAN, 2 (2), 129-142 